\title{
Understanding the rise and decline of shareholder activism in South Korea: the explanatory advantages of the Theory of Modes of Exchange
}

\author{
Bronwen Dalton $^{\mathrm{a}^{*}} \quad$ Marie dela Rama ${ }^{\mathrm{b}}$ \\ a. University of Technology, Sydney; ${ }^{b}$ University of Technology, Sydney
}

(Received May 31, 2015; accepted Dec. 2, 2015).

\begin{abstract}
The extent to which Korea has become a fully-fledged neoliberal state has been subject to debate. We argue that the recent rise and fall of shareholder activism in Korea is related to the coexistence of neoliberal and developmental state characteristics. Uncertainty as to "the rules of the game" during this uneven transition has provided the chaebol with an opportunity to defuse the radical potential of shareholder activism. Through an analysis of media reports this article argues there is a relationship between the rise of fall shareholder activism in Korea and a retreat from neoliberalism. It then discusses advantages of the theory of Modes of Exchange to make sense of these developments.
\end{abstract}

Keywords: East Asian Crisis, chaebol, corporate governance, minority shareholder movement, modes of exchange

\section{Acknowledgments}

The authors would like to acknowledge the kind guidance of the special issue editor, Professor Ingyu Oh at Korea University, the APBR editors, Professor Chris Rowley and Professor Malcolm Warner, and the anonymous reviewers.

\footnotetext{
* Corresponding author. Email: Bronwen.dalton@uts.edu.au
} 


\section{Introduction}

In South Korea, the 1997 Asian financial crisis and the 2007-08 Global Financial Crisis (GFC) unleashed forces that have driven a significant shift in the structures and practices associated with the developmental state. Externally, global capital is pressuring Korea to acquire more neoliberal characteristics. Internally, civic groups have adopted innovative forms of NGO-driven shareholder activism to realize corporate governance reform. This has created challenges for Korea's large conglomerates, the chaebol, as they seek to maintain their dominance in the Korean economy and pass on family ownership of their corporate empires to their heirs. Nevertheless, the chaebol have been relatively adroit in dealing with these external pressures and particularly effective in defusing the radical potential of Korea's minority shareholder movement (MSM). We argue that this is part of a broader process of maintaining developmental state characteristics in an era of neoliberal globalization through attempting to reduce once leftist inspired notions of "economic democracy" to the task of corporate governance reform (Doucette 2015). This article explains the sources of the chaebol's legitimacy problem in Korean society with reference to their distinct structure and governance arrangements. Afterwards, we analyse contemporary Korean media coverage and argue that the rise and decline of the MSM is related to a selective and uneven engagement with the neoliberal agenda. The paper concludes by examining the explanatory advantages of the theories of New Institutionalism and Modes of Exchange to make sense of these developments.

\section{Literature Review: The rise of the Korean Chaebol}

During an extended period of authoritarian rule and extensive state intervention in the economy, economic elites emerged in Korea that became closely connected to the central political authority as a way of maintaining their privileged position. The relationship between political and economic elites was largely based on the exchange of political donations and support in return for market privileges. During this period, the South Korean government channelled massive amounts of capital 
through subsidies and low-interest-rate loans into trusted chaebols. These favoured firms also enjoyed trade preferences and monopoly rights, among other indulgences extended by Korea's political elites (Oh and Varcin 2009).

Such preferential treatment enabled the chaebol to grow into massive business empires. But this government support came at a price. State bureaucrats were willing to provide this largesse including business permits or legal protection only if businesses or business owners remitted extracted payments to the former ( $\mathrm{Oh}$ and Varcin 2009).

However, as Korea has become highly exposed to the interconnected global economy, various features associated with more open and entrepreneurial markets have emerged. The fallout from two major financial crises, the Asian Financial Crisis in 1997-98 and the Global Financial Crisis in 2007-2008 exposed a weak, badly regulated financial system; wildly overleveraged firms; and occasionally corrupt corporate governance practices. These practices and other distinctive structural features have undermined the legitimacy of the chaebol in Korean society (Lim 2003).

\section{A legitimacy problem: the chaebol's distinctive structural and governance characteristics}

The large conglomerate business group is not unique to Korea however several features distinguish Korean chaebols from conglomerates in other countries. One distinctive characteristic is the extent to which chaebols have diversified their field of operations. The breadth of chaebols' operations is partly a by-product of a capital-raising strategy. For many decades, new firms could more easily obtain lowinterest-rate loans from the Korean government-controlled banks (Lee 1999). So in spite of the government's so-called 'specialization policy' introduced in 1991 to induce the chaebol to concentrate their investment resources into their core businesses, by the late 1990s, leading chaebols, such as Samsung, Hyundai, LG, and Daewoo, each had over 80 affiliated companies participating in a wide range of 
industries, including consumer electronics, semiconductors, construction, automobiles, trading, shipbuilding and financial services (Kim, Hoskisson, Tihanyi, Hong 2004). While the 1997 Asian financial crisis precipitated the re-structure and, in some cases, their collapse, Daewoo being a famous example, most survived and continued to expand (Bremner and Moon, 2002).

A second notable feature of the chaebol is the extent to which they dominate the Korean economy. In 2010, according to the federation of Korean industry, the largest 30 chaebol accounted for 84 per cent of total exports (Bloomberg 2012). They also account for most of the Korean stock market's market capitalisation. For instance, the Samsung Group's capitalisation to total market capitalisation ratio equalled about 21 percent in 2006 (Lim 2011).

A third distinctive feature of the chaebol is the extent of discretionary power of owner managers given that they own only a small proportion of shares. The source of owner-managers' discretionary power is through their control of the chaebol core or mother company, which in essence is a "control tower" system of group-wide oversight. In a study by Korea's Fair Trade Commission released in 2015, family ownership of stock at 41 groups with a family "chongsu" (an unofficial or unappointed general manager who makes the final corporate decisions for the entire syndicate) was found to be just $4.3 \%$ with $55.2 \%$ of the remaining internal equity owned by affiliates and executives (FTC 2015). The internal equity ownership rate for Samsung, Hyundai, SK, LG, and other conglomerates in the top ten rose from $46.4 \%$ to $53.6 \%$ in 2001 , while ownership for the controlling family actually dropped from $3.1 \%$ to $2.7 \%$ (FTC 2015). Chaebols are thus a variant of the controlling minority structure firm, where a shareholder exercises control while retaining only a small fraction of the equity claims on a company's cash flows (Lee 2002; Bebchuk, Kraakman and Triantis 1999; Chang 2003).

The controlling minority structure has allowed owners to transfer stock, capital and managerial resources among the chaebol group's affiliated firms often to prop up 
weaker affiliates (Lee 2000). One common intragroup transaction is awarding contracts to firms owned by family members, a practice known as tunneling (Bae et al 2008; Lim 2011; Nam, Kang and Kim. 1999; Choi, Lee, and Park 2007).

Outsider shareholders suffer from this form of internal trading among chaebol affiliates as firms buy products at over-inflated prices from sister companies even when non-affiliated firms offer better rates.

In this way chaebol governance arrangements have effectively insulated owners from the demands of shareholders or outside directors (Choi, Park and Yoo 2007). There are various indicators that highlight the weakness of chaebol minority shareholders. One is the large price gap between the common stocks and preferred stocks of Korean firms. The price of common stocks in Korea is often twice as high as that of preferred stocks in Korea (Baek, Kang and Park 2004). Another measure of shareholder rights is the amount paid to shareholders in the form of dividends. In the Korean chaebols the ratio of dividend rates relative to profits is typically around 20 percent compared to about 40 percent in the US and Japan (Lee 2002).

Anti-chaebol sentiment has been further fuelled by the chaebol owners' commitment to dynastic practices. In recent years there have been numerous battles over management rights and inheritances among chaebol families attempting to use a range of unconventional and often illegal methods from tunnelling to intra- firm real estate transactions to bypass Korea's hefty 50\% inheritance taxes. These battles have sparked a great deal of infighting among chaebol families themselves which in turn has heightened public resentment (Hwang and Kim 2014).

In the wake of the financial crisis, progress regarding chaebol corporate governance has been made with the Korean government strengthening the hand of minority shareholders by pressing the chaebol to remove mutual debt guarantees, crossshareholdings and other financial ties between affiliates (WSJ 2003). But in most of the family controlled chaebol there is still little shareholders can do to influence management decisions. ${ }^{\mathrm{i}}$ 
Due to the Korean conglomerates collusion with the state; its economic dominance of the economy; its failure to recognise shareholder rights, and its dynastic practices, the chaebol have a legitimacy problem in Korean society (Lim 2003). However for decades the state did little to directly respond to this sentiment and instead emphasized how the chaebol was an instrument of the social goal of national prosperity (Roh 2007). But the fall out after the Asian Financial Crisis had devastating economic and social consequences and took the reputation of the chaebol to rock bottom.

In the late 1990s unemployment soared (reaching 6.8\% in 1999); real wages steadily decreased (from 100 in 1997 to 98.1 in 2001); and casualisation of the workforce rose sharply (Shin, 2013). Together these factors led to unprecedented levels of income inequality, Park and Mah show how the Gini coefficient increased from 0.27 in 1997 to 0.31 in 1998 (Pak and Mah 2011). While, as Pirie argues, the cause of the GFC was externalised, the ongoing social hardship was seen to be the fault of the chaebol (Bloomberg 2012).

In response, the "chaebol problem" became the dominant issue in the 2012 presidential elections. This focus of the chaebol marks a departure from former elections which focussed on growth-first policies (Doucette 2015). Under the banner of "economic democratisation", both liberal and conservative parties placed welfare and economic democratisation through chaebol reform at the centre of their platforms. As Doucette (2015) argues, the focus led to a series of heated exchanges about the vision of economic democratisation being promoted: with one camp favouring the creation of a "fair market" through the restructuring of the chaebol and another promoting the protection of the chaebol's management rights over their affiliates as a desirable strategy for the creation of a Korean welfare state (Doucette 2015: 388). 
The use of the term "economic democracy" among political parties was long predated by Korea's progressive civil society organisations, which expanded rapidly following the transition to free elections in 1987. However, unlike the leftist anti-hegemonic ideology of labour and student based movements active during the decades of authoritarian rule (Koo 1993), for the post-democratisation breed of civic organisations, economic democracy came to be synonymous with chaebol governance reform. This was the case for two organisations in particular - the Citizens' Coalition for Economic Justice (CCEJ) and the People's Solidarity for Participatory Democracy (PSPD).

In the 1990s the CCEJ was the largest and best known of South Korea's anticorruption NGOs and was widely considered to represent the new simin undong tanch 'e [citizens' movement groups]. Its demands for "economic justice" centred on condemning the corrupt state-business relationship and an inadequate financial and tax system for triggering a host of economic and social problems. The PSPD was established in September 1994 initially led by Park Won-soon, a lawyer known for work representing dissidents and "comfort women" (women who were forced to serve as sex slaves for the Japanese imperial army in the 1940s). The stated goal of the PSPD was to "prevent the abuse of power by government, the judiciary and big business groups via the participation of citizens" (Park 2010). It committed to a variety of issues - from compiling files on judicial officials and their verdicts, monitoring parliamentary activities and conducting its "Transparent Society Campaign" (Kim 2003). More recently it has been the PSPD's focus on the issue of shareholder rights under the banner of the Minority Shareholders Movement (MSM) that has attracted the most public attention.

The CCEJ and PSPD are broadly representative of the main type of NGO that emerged in the 1990s in that they adopted a social justice agenda; were urbanbased; formed various linkages with other NGOs while remaining relatively independent from organised labour and political parties, and explicitly adopted 
legal and non-violent tactics centring on the development and mobilisation of organised popular opinion (Dalton and Cotton 1996). Also both groups drew their members overwhelmingly from Korea's influential middle-class. ${ }^{\text {ii }}$ After the 1997 crisis the CCEJ declined (and as Lim and Jang (2007) point out, many of its leading members took important positions in the government's economic ministries). However the PSPD remains active.

\section{Theory: Framing, New Institutionalism and Modes of Exchange}

The configuration of forces in Korea's political environment favoured the emergence of these types of citizen based movements. For Korea's Minority Shareholder Movement (MSM) the unresponsiveness of the government to chaebol excesses; the presence of supporting forces (in particular foreign capital seeking to invest in Korea) and the power configuration in the political society together created the political opportunity structure conducive to its formation and capacity to garner public support (McAdam 1982; Tarrow 1989; Brockett 1991). The political opportunity structure also suited MSM's adoption of more moderate strategies as they were in keeping with the orientation and organisational skills of their middleclass support base. Most importantly, however, was the availability and extension of new frames of meaning. Through actively engaging in the social construction of new meanings of economic democracy it created a new frame - that is a new construction of a shared interpretation of a problem (Snow and Benford 1988). This frame was linked to a variety of existing grievances with the chaebol through the language of corporate governance reform. To achieve this the MSM was particularly effective in using the mass media to extend this frame and garner wider public support (Kim and Park 2008).

For this reason theories relating to framing through the mass media are particularly relevant to the case of shareholder activism in Korea. 'Framing' is now an 
established field in mass communication studies. Entman (1993: 52) argues that the purpose of framing, 'is to select some aspects of a perceived reality and make them more salient in a communicating text, in such a way as to promote a particular problem definition, causal interpretation, moral evaluation, and/or treatment recommendation for the item described'. Similarly, Gitlin (1980: 7) defines media frames as 'persistent patterns of cognition, interpretation, and presentation of selection, emphasis, and exclusion, by which symbol-handlers routinely organise discourse, whether verbal or visual.' The pervasiveness of a particular frame can be demonstrated through an examination of the most commonly used metaphors in the media coverage of a particular issue. Vujakovic $(1998,153)$ points to metaphors as having social power, noting that ' $[t]$ he common acceptance of a particular metaphor (propagated or reinforced by the media) may lead to a limited view of an issue and the closure of constructive alternatives'. Theories relating to framing thus provide the theoretical foundation for the methodology of media content analysis used in this study.

The theories of new-institutionalism and MOE (Lie 1992; 1997) can also help us make sense of the rise and fall of shareholder activism in Korea.

Various scholars have sought to bring together the fields of sociology and economics to develop sociological understandings of the market. A group now known as New Institutionalists developed a theory that focuses on developing a sociological view of institutions - the way they interact and the way they affect society (DiMaggio and Powell's 2012; North 1981, 1990 Scott 2001; Brinton and Nee 1998). In a similar vein John Lie developed the sociological approach to the study of markets, to develop the theory of Modes of Exchange (MOE) (Lie 1992; 1997). 
As will be discussed, New Institutionalism and MOE theory help to understand the emergence and outcomes of the MSM have been shaped by dominant social relations and the current coexistence of mixed modes of exchange.

\section{Research Questions}

Both New Institutionalism and MOE theory illuminate various dynamics related to shareholder activism in Korea. In particular it can give greater insights into answering the following questions:

a) How can we explain the rise of shareholder activism in Korea?

b) What was the process of gathering the ethical and moral support from the populace to obtain legitimacy for MSM? Specifically, how did the MSM manage to re-frame what is considered "good" corporate governance in Korea.

d) How did the state or institutional owners, including chaebol families, try to neutralize shareholder activism in Korea? What was the role of the media in this process?

h) Why has support for shareholder activism in Korea declined?

\section{The Rise of Shareholder Activism in Korea}

Various scholars highlight the role shareholder activism can play in controlling corruption and promoting good governance (Iskander, Meyerman, Gray and Hagan, 1999; Spar, and La Mure 2003; Proffitt, and Spicer 2006). Shareholder activism can take many forms, such as proxy battles or shareholder resolutions put to the vote at annual general meetings.

However, in Korea, a lack of investor protection and almost non-existent shareholder rights have made these traditional methods of shareholder activism relatively impotent. Instead, shareholder activism adopted different strategies and 
was led almost exclusively by the nongovernmental organisations (NGO) (Park and Kim 2008).

The beginnings of the minority shareholders' movement (MSM) in Korea can be traced back to March of 1997, after the Asian financial crisis (Park and Kim 2008). At that time, the economic committee of the PSPD, the Participatory Economy Committee (PEC), spearheaded by Professor Jang Hasung of Korea University, launched the "Minority Shareholders' Movement (MSM)" which aimed to "scrutinize the internal operations of top chaebol in search of malpractices" (PSPD 2015; Park and Kim 2008; Choi, and Cho 2003; Kim, and Kim 2001; Jang and Kim 2002).

In terms of methods, the PSPD-backed PEC focussed on using the court system and class actions. These strategies included a repertoire of non-violent protest and lobbying methods such as petitioning, staging public debates, pamphlet distribution and monitoring committees. These methods have been described by Han-Kyun Roh as "legalistic pragmatism" (Roh 2007). As one PEC officer interviewed by Roh recalled:

We looked for a way of dealing with real-life companies. The answer was to become an [legally] interested party to the company, like shareholders, consumers and employees. (Interview on 11 October 1999 cited in Roh 2007, 66)

During the period from 1997 to 2001, the PEC filed 12 lawsuits, including 4 derivative suits. A major success was in March 1998 when it won a legal case against Korea First Bank's management board, which resulted in the court ordering the bank management to pay 40 billion won in fines for managerial failures. According to sociologists, Gil-Sung Park and Kyung-Pil Kim, this particular episode became: 
perhaps the most representative case of Korea's citizen-based activism in the field of economic reform following the 1997 financial crisis.... [this is] evidence that NGOs have arrived as main actors in the process of reforming corporate governance in Korea." (Park and Kim 2008, 60).

As the MSM matured it developed another innovative approach to shareholder activism, partnering with foreign investors who sought to leverage their position as shareholders to push for reform from within.

In 2006, and partly due to internal divisions regarding a change of focus from minority shareholders' rights to institutional investment as a means to reform, the Participatory Economy Committee (PEC) separated from PSPD and took on the new name Solidarity for Economic Reform (Hankyoreh 21, 2006). Jang Hasung also established the investment Korea Corporate Governance Fund (KCGF), under the management of Lazard Asset Management LLC, a New York-based asset manager. (In Korea the fund was commonly known as the Jang Hasung Fund). This fund then began to invest in a series of Korean companies judged to be undervalued due to poor governance practices. After becoming a shareholder, the fund then sought to actively address those governance problems, pressuring them to add outside directors and an audit committee, and then selling the shares after their proposals were adopted (Forbes Asia 2014).

A 2007 study showed that the stock prices of companies targeted by KCGF increased significantly on the announcement of the targeting (Kim E. Han and Kim 2008). For example, in August 2006 when the KCGF announced that it was buying $5 \%$ of Dae-Han Synthetic Fiber, within one month the company's stock price rose by over $200 \%$ (Kim and Kim 2008, 10).

In this way, local civic-based activists aligned with foreign investors managed to put pressure on the chaebol to realise some corporate governance reform while also 
turning a profit. However this financial success, particularly as it was in part achieved through to working with foreign investors, lead many to wonder if the MSM had begun to be more motivated by profit rather than shareholder rights.

\section{The decline of shareholder activism and the uneven uptake of neoliberalism in} Korea

In the early stages, the MSM was welcomed among the public. One reason was that it was relatively successful. Research by Choi and Cho shows that, of the 24 cases launched by MSM, 13 won their lawsuit or secured a majority vote for their proposals at various shareholders' meetings (Choi and Cho 2003). The MSM also won three of its eight general lawsuits and five of its eleven shareholder proposals were adopted (Choi and Cho 2003).

Leadership also played a role. Jang Hasung was celebrated as a popular and respected activist figure. In 1998 and 1999 Jang was included in Business Week's 50 Asian Stars for being one of Asia's best advocates of shareholders' rights and received one of the first International Corporate Governance Network (ICGN) Annual Awards in 2001 (Business Week 1998; 1999).

MSM also had appeal as it aligned with generally positive views of civil society organisations. Many Koreans are proud of the critical role civil society organisations played in driving Korea's democratisation. As Lim and Jang argue "As major legitimacy-bearers and legitimacy-producers in post-democratic South Korea, NGOs were considered public watchdogs representing or embodying a just civil society" (Lim and Jang 2006, 459).

More fundamentally the movement benefitted from the political opportunity structure and framing of their issue in a way that tapped into middleclass values and strong anti-chaebol sentiment. The MSM social construction of economic 
democracy had "frame resonance" in that it was relevant to existing popular understandings (Snow, Rochford, Worden and Benford 1986).

Over time, however, the movement lost much of its popular support. Some scholars argue that its decline was related to the growing hegemony of neoliberalism in Korea (Lim and Jang 2006; Kim and Park 2008). This is related to a general consensus that in recent years Korea has experienced a pronounced shift toward the neoliberal model (Hall, 2003; Kim, 1999; Ha and Lee, 2007; Hundt, 2005; Lee, 2006). As Lee and Kwak's (2009) review of the literature points out, these authors refer to three types of evidence - the establishment of an independent financial regulator; the dramatic increase in foreign ownership of financial institutions (by 2003 foreigners owned more than $34 \%$ of Korean shares by value, up from just $13 \%$ at the end of 1996 WSJ 2003) and the segmentation policies for banking, securities, and trust activities - as evidence to support the view. It is argued that these reforms precipitated the institutional death of the Korean developmental state (Hundt, 2005; Lee, 2006).

Lim and Jang (2006) explicitly link the rise of neoliberalism with the decline of the MSM. They argue that due to the movement's dependence on legalistic and technical discourses that emphasised shareholders' rights over the interests of other stakeholders, such as workers or other subaltern groups, the MSM contributed to the establishment of the core neoliberal principle - the inviolability of exclusive private ownership. They argue that the MSM's approach provided neoliberalism with the "much needed political and moral legitimacy as a hegemonic project in the drastically changed environment that was South Korea after the 1997 crisis" (Lim and Jang 2006, 451).

However, some question the neoliberal convergence thesis as it applies to Korea (Lee and Kwak 2009; Pirie 2015). Pirie (2015) argues that there was a selective retreat from neoliberalism post the GFC. This retreat was related to various groups 
in Korea including the government constructing the GFC as a failure of a global, Western-dominated financial system (Pirie 2015). This construction of the GFC as an exogenous threat is relevant to how shareholder activism came to be viewed as an agent of hostile foreign interests. A media content analysis shows how such sentiments became evident during the attempts of a Monaco-based investment fund, Sovereign Asset Management Ltd, to take control of South Korea's largest oil refiner, SK Corp.

In 2003, when the stock of SK Corp. plummeted after news broke of a multibilliondollar accounting scandal at an affiliated company, Sovereign bought nearly $15 \%$ of SK Corp. Shares. Sovereign argued that bad corporate governance under the leadership of the family chongsu Chairman Chey Tae-won dented the value of SK Corp. and that its stock would rise if they removed Chey. At one stage this looked possible as Chey was jailed on charges of fraud. However, in August 2003 Chey was released on bail and then successfully secured the backing of local banks to support him in the March 2004 shareholders meeting where shareholders voted against Sovereign's attempt to oust the company's board. In 2005, Sovereign Asset Management's sold its investment in SK Corp at a $\$ 700$ million profit. At the time of writing, the Chey family still control SK Corp. and Chey Tae-won was reported to have been the most highly paid among Korea's corporate CEOs earning nearly \$26 million in 2014 (Chosun Ilbo, 1 April 2014).

\section{Methodology: Media content analysis}

Through its interpretation of events, the media can influence the way an issue is discussed and evaluated and in this way influence individual perceptions (Gamson 1988). The ways media frames a given event or issue is central in determining whether audience perceptions are largely positive or critical. This is because media frames tend to offer 'moral judgment' reflective of 'specific ideology', forwarded through the use of carefully selected words, metaphors and phrases, which set the 
“"tone" of media coverage' (Saleem 2007, 134-5). Headlines are particularly influential. Steuter and Wills $(2009,9)$ argue that they play a significant role not only in communicating and encapsulating article content, but in 'influenc[ing] and direct[ing]' audience interpretation, perception and evaluation of the reported issue as a large proportion of a newspaper's readership will form an understanding of reported topics based on a scanning of headlines, rather than a full reading of featuring articles (Steuter and Wills 2009, 13).

Our analysis initially examined the headlines of reports on the SK Corp/Sovereign' case in the Korea-based and international English language media to ascertain the extent to which lexical and broader framing choices reinforced an interpretation of foreign investment.

\section{Sampling}

To generate relevant headlines for analysis we sampled all English language articles sorted by relevance that appeared between 1 January 2003 to 1 January 2004. The query used the general name for the companies, 'SK Corp', and 'Sovereign'. This process also allowed a large number of media articles to be reduced to a more manageable sample (Riffe et al. 2008). Then, using the same query, the search was conducted on all English language publications based in Korea. This second search generated 416 articles. The search included The Chosun Ilbo, Dong-A Ilbo, and Jung-Ang Ilbo which are conservative in orientation; the Hankook Ilbo and The Hankyoreh the major progressive newspapers and the two major business newspapers Maeil Business Newspaper and Korea Economic Daily. All of these newspapers publish English and vernacular versions of each issue.

\section{Coding operation}

To indentify the dominant metaphors used in the Korea-based media, coding was conducted to convert the raw data into a standardised form (Babbie 2003). There has not been any systematic research undertaken on media representations of the 
Sovereign case so the coding categories were developed in an inductive and exploratory way. Coding categories of both manifest and latent content were created to balance out their respective shortcomings. The software package NVivo 8 by QSR was used to code both types of content.

The surface, or manifest, content categories are specific words. The manifest content was developed using the word frequency query available in NVivo 8, to gain an understanding of some of the common language used. Some 100 of the most commonly occurring words were extracted and grouped into categories.

\section{Data analysis}

During the 2003-2004 Sovereign vrs SK episode there was a particularly sharp increase in foreign direct investment in Korea. Total notifications of foreign direct investment (FDI) in 2004 amounted to US\$12.77billion, up 97.4 percent on the US $\$ 6.46$ billion from 2003. Merger and acquisition investments increased by 84.5 percent over the 2003-2004 period. Major cases of FDI in 2004 included the takeover of Hanmi Bank by Citigroup of the United States for US\$1.71 billion, the creation of the US\$930-million joint venture firm of S-LCD by Samsung and Sony of Japan, and the takeover of Ssangyong Motors by Shanghai Automotive Industry Corp. After investing during this period some foreign investors exited and made substantial profits in the process. For example, in 2003, Dallas-based Lone Star Funds bought a controlling stake in Korea Exchange Bank and, after a decade long legal battle, won approval to sell the bank to Hana Financial Group in 2012 making $\$ 4$ billion profit (Bloomberg 2012); in 2004 the U.K.-based fund Hermes Investment Management Ltd sold its shares in Samsung Corp. for about \$100 million profit; and in 2006 the Carl Ichan led US-based Icahn Partners' Master Fund successfully pressured tobacco firm KTandG Corp. to pay out $\$ 3$ billion to its shareholders, netting a $\$ 120$ million capital gain in the process (Forbes 2015). 
During this period a narrative began to emerge in the Korean media that expressed unease with foreign investment. Headlines such as the following dominated the major dailies: "Calls for Tightening M and A Rules Rejected (Korea Times, 7 April 2004); "Barriers to hostile takeovers in Korea" (The Korea Herald, 2 July 2003); "KCCI urges better defence against hostile takeovers (The Korea Herald, 29 October 2003; SK Safe From Foreign Hostile Takeover Bid (Korea Times, 16 April 2003); and "Seoul to protect chaebol against hostile MandAs." (The Korea Herald, 23 April 2003). In the case of Soveriegn, headlines like "Don't try to know much about us" (The Korea Times, 22 December 2003) and "Non-Transparent Sovereign Fails to Win Hearts of Koreans" (The Korea Times, 16 March 2004) were typical of a growing distrust of Soveriegn's intentions. In contrast reporting in the nonKorean press often defended the rights of international investors. Table 1 compares the headlines of Korean and non-Korean press regarding Sovereign and SK Corp over the 24 month period January 2003 to January 2004.

[Insert Table 1 here].

Figure 1 shows that a search of all Korean News Publications for articles with the words "Sovereign" and "SK Corp" from 1 January 2003 to 1 January 2006 generated 416 articles. An analysis of these articles shows the frequency of the appearance of relatively negative descriptor terms regarding Sovereign's actions. Based on the frequency of certain key words, the dominant metaphors identified a group of conflict metaphors including the terms "hostile", "oust", "takeover" and "battle".

[Insert Figure 1 here]

These metaphors contribute to constructing 'facts' about foreign investors interests and motivations, in particular that their motives are not so much about Korean corporate governance reform but about making quick profits. It is noticeable that 
this narrative was particularly strong in the conservative press. In February 2004 Sovereign placed a series of full-page advertisements in leading newspapers. However, days later SK Corp retaliated paying for a number of colour advertisements in The Chosun Ilbo and Dongah Ilbo while Sovereign's agents said that these conservative dailies told them that there was no space available for their advertisements (The Economist 2004). Sovereign settled for a campaign on the internet, but this event shows that incumbent controlling Korean shareholders and high-level executives of major Chaebols effectively used their power over some parts of the media to counter the actions of Sovereign.

In this context, representatives of the MSM voiced support for foreign investors. Head of the PSPD Economic Reform Center, Kim Sang-jo argued:

A public backlash against overseas capital is not desirable. When takeover attempts are made, share prices of the targeted corporations rise in most cases. Increases in share prices indicate that external interference in corporate management is an effective means of enhancing corporate efficiency. Could the enhancement of efficiency be realized automatically without external interference? The answer is negative (Kim 2006).

In another statement Kim Sang-jo said "Koreans should not condemn foreign investors' legal activities just because they profit from them" (JoongAng Daily, 17 July 2005).

The MSM's defence of foreign investment has been a major driver behind the reevaluation of the movement. By lending its support to Sovereign's campaign to transfer the ownership of the SK Corp from the Chey family, shareholder-activists were criticized for not condemning the perceived speculative characteristics of transnational finance. Instead headlines decried how the movement had become a vehicle for foreign capital to make quick profits at the expense of local interests. This headline from the Korea Herald that appeared in June 2008 sums up the mood: 
"From Corporate Governance Champion to trojan horse of hostile takeovers:

Corporate Governance turns a profit". The article goes on:

Was the fund about corporate governance reform or making money? The proposal was to do both unlocking shareholder value through generating corporate governance reform? It appeared to have failed in both. (The Korea Herald, 19 June 2008).

In this way, many Koreans ongoing struggle surrounding the "nationality of capital" has implicated the shareholder rights movement. This reaction to the MSM's connections with international capital is particularly interesting in the light of sociologist Park Gil Sung's thesis that transnationalisation of the middle class has added a new dimension to the gap between social classes in Korea (Park, 2004).

\section{Discussion: The decline in support for Korea's MSM and the retreat from Neoliberalism}

The decline in support for Korea's MSM is emblematic of broader forces driving the construction of the Global Financial crisis as a failure of a global, Westerndominated financial system and a consequent selective retreat from neoliberalism (Pirie 2015). This retreat that was made easier as both the chaebol and those in the MSM had only ever partially endorsed the neoliberal agenda.

The chabeol was clearly in favour of privatisation, increased labour market flexibility and the tightening of market disciplines (Lee et al. 2010). However, the chaebol were less enthusiastic about the opening of key domestic markets, which they dominated, to foreign competition and the weakening of systems of industrial support from which they benefitted (Pirie 2015).

The MSM endorsed pro-neoliberal inspired reforms to corporate governance but also accepted that the chaebol has a potentially complementary role in laying the basis for a broader social compromise that leads to the development of a Korean 
welfare state (Doucette 2015). For example Kim Sang-jo, the director of Solidarity for Economic Reform and a leading minority shareholder activist, uses the phrase "fair market economy" to describe a process of establishing firm rules for the dispensation of justice concerning the questionable activities carried out by the chaebol and that the chaebol should be made to enter into the framework of social cooperation, producing economic democratisation (Kim 2012). Similarly, civic leader and political economist Lee Byeong-cheon (2012) advocates that chaebol reform is the gateway to a "symbiosis" in which independent businesses flourish in every corner of society and high-quality jobs increase.

Unlike past interpretations of economic democracy, the MSM's vision of economic democracy did not champion a redistribution of wealth. This is consistent with their middleclass origins. Despite the expression of liberal attitudes at certain points in Korean history, Korean scholars argue that overall the Korean middle-class is conservative and opportunistic in character and that middle-class support for the workers and students movement has always been conditional and selective (Choi 1985; Dong 1993; Park 2004; Lee 2007). Civic leader and director of the Association for Economic Justice Jeong Seung-il describes this version of economic democracy as follows:

the economic democratisation asserted by the minority shareholders' campaign is merely wealth redistribution among some hundreds of thousands of stock market investors and some ten to twenty thousand American and British investors. The minority shareholders' campaign has clearly reached some partial level of economic democratisation, but it has merely resulted in the even redistribution of wealth and property that was once monopolized by a privileged group of chaebol and top officials to... members of the upper class. Economic democratisation occurred, but it only impacted some hundreds of thousands of people (quoted in Hankyoreh 21 2006). 


\section{The relative explanatory power of the theories of new-institutionalism and Modes of Exchange (MOE) to understand the rise and fall of shareholder activism}

The theories of new-institutionalism and MOE (Lie 1992; 1997) can help us make sense of the rise and fall of shareholder activism in Korea. Both newinstitutionalism and MOE locate social actors in a network of personal relationships "characterised by certain norms, in accordance with which they evaluate - reward and punish - each other" (Brinton and Nee 1998, 40). Both theories thus help explain how Korea's economic and political elites and shareholder activists embeddedness in dominant social relations shaped the emergence and outcomes of the movement. In particular, conditioning institutional factors shaped the structure of incentives open to middle class shareholder activists. The current foundering of shareholder activism underscores how shareholder activists themselves are embedded in these social relations. Due to their class location and the unstable character of middleclass interests they are particularly vulnerable to co-option by the state or business. As discussed many of the other main middle class NGO that emerged in the 1990s, the CCEJ's, many of its leaders have taken on jobs in government (Lim and Chang 2007). For these reasons the middle class-based MSM is more likely to become a force for moderation not democratisation, harnessing the energies of an ideologically malleable middle-class and preventing their alignment with more radical political alternatives (Paek 1993). As Jang Hasung himself observed: "The chaebol have political power. The corporate sector has influence in every corner of society. There's no diversification.... Retired bureaucrats, judges, everyone wants a job in a chaebol" (quoted in Forbes Kirk 2014).

The theory of Modes of Exchange (MOE) adds another heuristic dimension to understanding the rise and fall of Korean shareholder activism. MOE theory builds on new-institutionalism with its argument that the spread of ideas is only one precondition for system change. The modes of economic exchange also must change. But in Korea there has been no complete transition from one economic 
mode or exchange to the other. In this context, Korea's political and economic elites and civic groups absorbed neoliberalism only as a partially decontested package. Despite heated debate over what constitutes "economic democracy", ultimately the prevailing vision of economic democracy is neither neoliberal or developmental in orientation but limited to a debate around different approaches to chaebol governance reform. As such economic democracy is focused on intra-class (among those with capital) as opposed to inter-class (labour and capital) relations (Doucette 2015). As the creator of MOE theory, John Lie, points out, any complete adoption of neoliberalism would require a transition from the current mixed market and entrepreneurial modes of exchange to a fully entrepreneurial mode, a transition that would need to be accompanied by intense inter-class confrontations (Lie 1992).

\section{Conclusion}

Korea's rapid post-war economic development path was characterised by the emergence of a symbiotic relationship between government and businesses that was at the core of Korea's developmental state. This relationship shaped the emergence of uniquely Korean corporate structures and governance arrangements within South Korea's large conglomerates, the chaebol. However, as the Korean economy has globalised and democracy has matured, the country has become more exposed to exogenous economic shocks. The 1997 East Asian Crisis triggered the collapse of a string of chaebols and heightened pressure to reform their corporate governance arrangements in ways that promote greater transparency and accountability to shareholders. One NGO in particular, the People's Solidarity for Participatory Democracy (PSPD), took up the cause of minority shareholders initially through its adoption of legalistic methods.

By the mid-1990s the focus of shareholder movement shifted emphasis away from minority shareholders' rights to institutional investment as a means to reform. With 
the backing of foreign investors, it attempted to use its leverage as a block shareholder to push for reform. However, since the well known Sovereign versus SK Corp case in 2003-2004, the popularity of the minority shareholder movement (MSM) has dwindled. Meanwhile the chaebol's family ownership model not only remains intact but is in the process of inter-generational renewal. This suggests that pronouncements of the death of developmental state and the birth of a new neoliberal Korea are premature.

MOE theory builds on new-institutionalism with its argument that the spread of ideas is only one precondition for system change. Any complete adoption of neoliberalism would require a transition from the current mixed market and entrepreneurial modes of exchange to a fully entrepreneurial mode, a transition that would need to be accompanied by intense inter-class confrontations (Lie 1992).

As Park and Kim (2008) argue, while the minority shareholders' movement gave birth to many new possibilities and hopes toward civil society in Korea, it ultimately foundered due to its legalistic and single-issue focused methods and in not providing a true alternative model for reform. This was due to an ultimately conservative and narrow definition of economy democracy as being synonymous with corporate governance reform. As civic leader Jeong Seung-il observes, "We originally wanted economic democracy. Yet what we gained was shareholder capitalism" (Jeong 2004, 373). 
Table 1: Comparison of headlines of Korean and non-Korean press regarding Sovereign and SK Corp.

\begin{tabular}{|c|c|c|}
\hline Timeline & Non Korean media & Korean media \\
\hline \multicolumn{3}{|l|}{2003} \\
\hline $\begin{array}{l}\text { April } \\
\text { April } 10 \text { Sovereign announces } \\
\text { acquisition of } 12.99 \% \text { of SK Corp. } \\
\text { April } 14-16 \text { Sovereign says it purchased } \\
\text { SK Corp. shares to improve governance. } \\
\text { Sovereign announces its total purchase of } \\
\text { a } 14.99 \%\end{array}$ & $\begin{array}{l}\text { Investment fund to make bold reforms at SK Corp. Financial Times, } \\
14 \text { April } 2003 \\
\text { Sovereign faces SK Corp probe. Financial Times, } 16 \text { April } 2003 \\
\text { Stakeholder Speaks Out To Koreans The New York Times, } 29 \text { April } \\
2003\end{array}$ & $\begin{array}{l}\text { SK Turtles Up in Face of Hostile Takeover, Chosun Ilbo, } 15 \text { April } 2003 \\
\text { Sovereign plans indirect influence on LG units The Korea Herald, } 22 \\
\text { February } 2005 \\
\text { POSCO Favoured as White Knight for SK Corp. Korea Times, } 16 \text { April } \\
2003 \\
\text { SK rules out hostile takeover by Crest. Maeil Business Newspaper, } 15 \text { April } \\
2003\end{array}$ \\
\hline $\begin{array}{l}\text { June-July } \\
\text { June } 15 \text { SK Corp. board members } \\
\text { approve debt-equity swap for its troubled } \\
\text { trading unit, SK Global, (renamed SK } \\
\text { Networks later in the year). }\end{array}$ & $\begin{array}{l}\text { Korea Corporate Reform Hits Snags - Fight by Chandler Brothers } \\
\text { For SK Group Transparency Reflects Investor Obstacles. The Asian } \\
\text { Wall Street Journal, } 4 \text { June } 2003 \\
\text { Sovereign threatens to block SK Global deal. Financial Times, } 4 \\
\text { June } 2003 \\
\text { Sk Global Bailout OK'd Amid Foreign Dissent, Dow Jones News } \\
\text { Service, } 18 \text { June } 2003 \\
\text { Deja vu in South Korea, Institutional Investor - International, } 1 \text { July } \\
2003 \\
\text { Purchase Of Shares Reignites Governance Debate In Korea, The } \\
\text { New York Times, } 24 \text { July } 2003\end{array}$ & $\begin{array}{l}\text { SK Corp. shareholder tries to stymie debt-equity swap. JoongAng Daily, } 11 \\
\text { June } 2003 \\
\text { SK Braves Lawsuits to Rescue Trading Unit. Korea Times, } 12 \text { June } 2003 \\
\text { SK Group faces major governance reform. The Korea Herald, } 17 \text { June } 2003 \\
\text { Investors vote with their money against SK bailout. JoongAng Daily, } 17 \\
\text { June } 2003 \\
\text { Sovereign lashes out at Hana Bank president. } \\
\text { JoongAng Daily, } 9 \text { June } 2003 \\
\text { SK, creditors unite to repel foreign investor's challenge. The Korea Herald, } \\
6 \text { June } 2003 \\
\text { Chaebol Owners Raise Ante Against Hostile Takeover. Chosun Ilbo, } 6 \text { June } \\
2003\end{array}$ \\
\hline
\end{tabular}




\section{November- December \\ Nov. 20 Sovereign says company will}

elect able managers at an annual

shareholders meeting in March 2004

Dec. 22 Sovereign files a cout

injunction against SK Corp. and its five

top executives

Dec. 23 Seoul District Court rejects

Sovereign's injunction

\section{4}

Jan. 29 Sovereign announces five

candidates for SK Corp.'s board o

directors Jan. 30 SK Corp. announces

corporate reform plan

Feb. 22 SK Corp. announces 12 outside

director candidates. SK Corp. board

decides on resignation of three members,

incl. SK group Chairman Son Kil-seung

Feb. 25 Sovereign calls Chairman Chey

to resign

March 12. Chey family succeeds in

securing managerial rights at AGM
Sovereign fights in Korea to encourage change, Financial Times, 15 December 2003

Fund looks to challenge status quo in South Korea, Financial Times,

15 December 2003

Investor Suffers Setback in Fight With SK Corp. Korean Court

Korean Oil Refiner Returns Fire In Battle with Big Shareholder. The Wall Street Journal, 16 November 2004
Allows Sale Of Shares, The Wall Street Journal, 24 December

\section{Sovereign Demands Changes on SK Board.}

Chosun Ilbo, 21 November 2003

Foreigners Hold $44 \%$ of Shares of Top Groups.

Chosun Ilbo, 27 October 2003

'Don't try to know much about us'.

The Korea Herald, 22 December 2003

South Korea's chaebol: A Sovereign remedy? Foreign investors bie

on big business The Economist $26 \mathrm{Feb} 2004$

Crusading brothers behind coup in Korea - Sovereign Asset

Management, Financial Times, 8 March 2004

Sovereign Asset to appeal SK Corp ruling. Financial Times, 22

December 2004

Sovereign puts \$1bn into 'model chaebol' LG. Financial Times, 18 February 2005

Sovereign gives up plan to 'influence' SK Corp. Financial Times, 21 June 2005

Sovereign abandons its quest to oust Chey Tae-won - SK Corp.

Financial Times, 22 June 2005
SK Corp., Sovereign Able to Compromise, Professor Says Yonhap English

News, 3 February 2004

Sovereign, SK Corp. reach showdown - Monaco-based fund seeks control of leading oil refiner The Korea Herald, 11 March 2004

SK-Sovereign Showdown Gets Global Attention

Korea Times, 8 March 2004

Non-Transparent Sovereign Fails to Win Hearts of Koreans, Korea Times, 16 March 2004

New rules to help firms ward off hostile takeovers

JoonAng Daily, 3 January 2005 
Figure 1: Korean News Publications* Search "Sovereign AND SK Corp" from 1 January 2003 to 1 January $2006(n=416)$

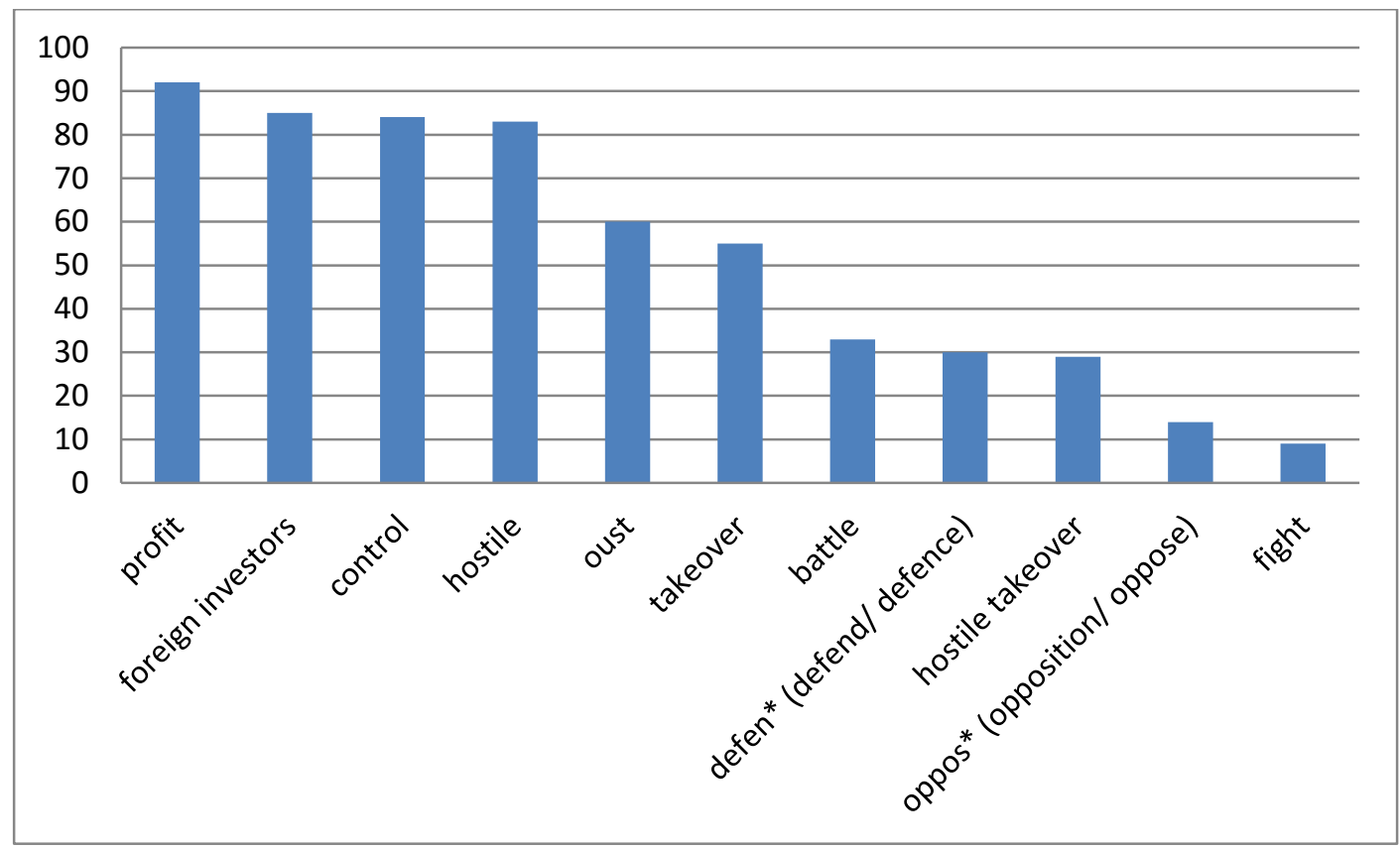

*All South Korea- based Publications including Web News in English

Source: Factiva

Notes:

1 In a study carried out by the Korean Fair Trade Commission (FTC) of 238 listed companies that are part of 46 chaebol, only $0.6 \%$ of 5,692 motions 
raised in board meetings between May 2011 and April 2012 were not approved as proposed because of opposition from an external director (Hangyoreh Simun "Park government stepping back from proposed restrictions on chaebol" Aug.8, 2013).

${ }^{2}$ A 1994 survey of CCEJ members found that the majority were employed in the tertiary sector, with politicians, academics and medical, arts and culture, legal, small business, office and government workers 


\section{References}

Baek, J. S., Kang, J. K., and Suh Park, K. 2004. "Corporate governance and firm value: evidence from the Korean financial crisis." Journal of Financial Economics, 71 (2): 265-313.

Bebchuk, L., R. Kraakman, and G. Triantis. 1999. "Stock Pyramids, CrossOwnership, and Dual Class Equity: The Creation and Agency Costs of Separating Control from Cash Flow Rights.” Discussion Paper No. 249, Harvard Law School, Olin Center for Law, Economics, and Business.

Campbell, J. L. 2004. Institutional Change and Globalization. Princeton, NJ: Princeton University Press.

Campbell, J. L. 1998. "Institutional analysis and the role of ideas in political economy." Theory and Society. 27(3): 377-409.

Baek, J. S., Kang, J. K., and Suh Park, K. 2004. "Corporate governance and firm value: evidence from the Korean financial crisis." Journal of Financial Economics, 71(2), 265-313. 
Bloomberg. 2012. "Koreans fret world-beating chaebol destroy small business", November 13; accessed at http://www.bloomberg.com/news/articles/2012-1112/s-koreans-fret-world-beating-chaebol-destroys-small-busi, 9 April 2015.

Bloomberg . 2012. "Hana Finishes \$3.9 Billion Korea Exchange Bank Takeover." February 9, 2012. http://www.bloomberg.com/news/articles/201202-09/hana-completes-3-9-billion-takeover-of-korea-exchange-bank-fromlone-star

Brinton, M. C., and Nee, V. .Eds. .1998. The New Institutionalism in Sociology. Russell Sage Foundation.

Brockett, C. B. 1991. "The Structure of Political Opportunities and Peasant Mobilisation in Central America”, Comparative Politics, April: 254-274.

Business Week. 1998. "The Stars Of Asia.” June 28, 1998 www.bloomberg.com/bw/stories/1998-06.../the-stars-of-asia-intl-edition 1999 - 1999. “The Stars of Asia.” June 14, 1999 www.businessweek.com/1999/99_24/b3633031.htm

CCEJ. 1994. Citizen's Coalition for Economic Justice Fourth Anniversary Yearbook. 1994 
Chang, S. J. 2003. "Ownership structure, expropriation, and performance of group-affiliated companies in Korea." Academy of Management Journal 46 (2): $238-253$.

CBRE .2015. Seoul MarketView Q1 2015

http://www.cbrekorea.com/EN/research/Pages/koreareports.aspx

Choi, Jang Jip .1985. “40 nyŏn haebanghu kukka, kyegup wa chŏngch’i soggae." Introduction to the State, Class Structure, and Political Change in the 40-year period after Liberation. in Choi Jang Jip .ed.. Han'guk Hyŏndaesa .Contemporary Korean Affairs. Seoul: Ylum-sa.

Choi, J. J., S. W. Park and S. S. Yoo. 2007. "The Value of Outside Directors: Evidence from Corporate Governance Reform in Korea." Journal of Financial and Quantitative Analysis, 42: 941-962.

Choi, W.Y, and S. H. Cho. 2003. "Shareholder activism in Korea: An analysis of PSPD's activities." Pacific-Basin Finance Journal 11(3): 349-363.

Dong, W. M. 1993. "The Democratisation of South Korea: What Role Does the Middle-class Play?" in Cotton, James, ed. Korea Under Roh Tae-Woo: 
Democratisation, Northern Policy and Inter-Korean Relations. Allen and Unwin, 1993.

Dalton, B. and J. Cotton. 1996."New social movements and the changing nature of political opposition in South Korea" in Rodan, Garry, ed. Political Oppositions in Industrialising Asia. Abingdon: Routledge.

Entman, R. M. 1993. "Framing: toward clarification of a fractured paradigm." Journal of Communication 43 (4): 51-58.

Doucette, J. 2015. Debating Economic Democracy in South Korea: The Costs of Commensurability, Critical Asian Studies. Vol. 47, Iss. 3. 388-413.

The Economist. 2004. "South Korea's Chaebol: A Sovereign remedy? Foreign Investors Take on Big Business.” Feb 262004. http://www.economist.com/node/2460847

Fair Trade Commission. 2015. Year 2015 Information on Ownership and Corporate Structure of Enterprise Groups, 10 June 2015 available at: http://www.ftc.go.kr

The Financial Times. 2004. "S. Korea's Business Giants Seek to Repel Invasion Force, 24 November 2004 By FIFIELD, ANNA, 
http://www.ft.com/intl/cms/s/0/be1b9ba8-3dbf-11d9-abe0-

$\underline{00000 \mathrm{e} 2511 \mathrm{c} 8 . \mathrm{html}}$

Forbes. 2015. "Surprise, Surprise! Korean Court Favors Samsung

Heirs In Merger Fight With Elliott For Inheritance.” by Donald Kirk $7 / 01 / 2015$

http://www.forbes.com/sites/donaldkirk/2015/07/01/samsung-heirsvictorious-in-court-decision-needed-for-merger-to-insure-theirinheritance/

Gamson, W. 1988. "Political Discourse and Collective Action." in B. Klandermans, H. Kriesi and S. Tarrow .eds., From Structure to Action: Comparing Social Movement Research Across Cultures 219-246, JAI Press.

Gitlin, T. .1980. The Whole World is Watching: Mass Media in the Making and Unmaking of the New Left, Berkeley, CA: University of California Press.

Hankyoreh. 2015. “Chaebol Families Dominate, But Own Only Small Portions of Their Groups.” Jul.3, 2015.

Hankyoreh 21. 2006. "Looking at Both Sides of the Jang Hasung Fund" Sep.19, 2006. 
Hundt, D. 2005. "A Legitimate Paradox: Neoliberal reform and the Return of the State in Korea." Journal of Development Studies 41(2): 242-260.

Hwang, S. W., and W. C. Kim. 2014. "When Heirs Become Major

Shareholders: Evidence on Tunnelling and Succession Through

Related-Party Transactions," ECGI - Finance Working Paper

No. 413/2014 .2014.

Lee, Keun. 2002. "Linking Corporate Governance to Firm Behaviour and Performance: The Case of Korean Chaebols Viewed as a Leveraged CMS Firm", Managerial Finance 28 (10):19 - 32.

Lim, Hyun-Chin and Jin-Ho, Jang. 2006. Neoliberalism in Post-Crisis South Korea: Social Conditions and Outcomes. Journal of Contemporary Asia 36 (4): 442-463.

Iskander, M., Meyerman, G., Gray, D.F. and Hagan, S. 1999. "Corporate Restructuring and Governance in East Asia." Finance and Development, 36 (1): $42-5$.

Jeong, S. I. 2004. "Juju iikk ukdaehwa uni ham ui”" .The implications of maximizing shareholder Value.. Chan-Geun Lee et al. Hankuk ky־ongjega sarajinda. Seoul: 21century Books. 
Kang, Won. 2009. The Changing Face of Korean Finance Management in Chris Rowley and Yongsun Paik eds. The Changing Face of Korean Management. Abingdon: Routledge.

Kim E. Han and Woochan Kim. 2008. "Changes in Korean Corporate Governance.” Journal of Applied Corporate Finance 20 (1): 1-12.

Kim, H., R. E Hoskisson, L. Tihanyi, J. Hong. 2004. "The Evolution and Restructuring of Diversified Business Groups in Emerging Markets: The Lessons from Chaebols in Korea.” Asia Pacific Journal of Management, 21 $(1-2): 25-48$.

Kim, Sang-jo. 2006. Pitting Foreign Capital against Domestic Capital is Undesirable. Korea Focus. http://www.koreafocus.or.kr/design1/layout/content_print.asp?group_id=101 172

Kim, Sang-jo. 2012. Chonghoeng Mujin Hangook Kyoungje: Chaebolgwa Mop'iaui Hapcheongeso T'alch'ul Hara [The Korean Economy Inside Out: Escaping the Trap of the Chaebol and MOF-ia]. Seoul: Ohmybooks.

Kim, Sang-jo .2012. 'Kyoungje Minjuhwaneun 'Chaebolkaehyuk' 'Yangukhwa Haeso'da" [Economic Democratization Is 'Chaebol Reform' and 'Polarization Resolving']. Solidarity for Economic Reform. September 
18. Accessed July 20, 2015.

http://www.ser.or.kr/sub.html?sub=commandpn=ecorevandm= viewandarticle_id=19547

Kim, Sunhyuk. 2003. "Civil society in Democratizing Korea." in Sammuel Kim .ed. Korea's Democratization 81-106. Cambridge University Press.

Kim, Yun-tae. 1999. "Neoliberalism and the Decline of the Developmental State." Journal of Contemporary Asia 29 (4): 441-461. doi:10.1080/00472339980000231

The Korea Herald .2006. "SK Group Governance Reform Pays Off." 15 December 2006.

Klandermans, Bert. 1992. "The Social Construction of Protest" in Aldon D. Morris and Carol McClurg Mueller .ed. Frontiers in Social Movement Theory. New Haven and London: Yale University Press. 77-103.

Forbes Asia. 2014. “Arresting Developments” by Kirk, Donald 5 May 2014 Forbes Volume 10 Issue 6.

Koo, Hagen. 1993. "The State, Minjung, and the Working Class in South Korea" in Hagen Koo .ed.. State and Society in Contemporary Korea. Ithaca: Cornell University Press: 144-145. 
Lim, Hyun-Chin and Jin-Ho Jang. 2006. Neoliberalism in Post-Crisis South Korea: Social Conditions and Outcomes, Journal of Contemporary Asia 36 (4): 442-463.

Lee, Byeong-cheon. 2012. “Chaebolgwa T'ahyeophagi Cheone Him Issge Butich'yeora" [Before Compromising with the Chaebol, Stand Up to Them Firmly]. Pressian July 3.

http://www.pressian.com/news/article.html?no=106606

Lee, Hyun-Chool. 2007. The Ideological Disposition of Koreans, Journal of Contemporary Asia, 37 (4): 472-494.

Lee, Keun. 2000. "Corporate Governance and Growth in the Korean Chaebols: A Microeconomic Foundation for the 1997 Crisis." Seoul National University Working Paper Series Vol. 2000-01 February.

Lee, Sook Jong. 2008. The Politics of Chaebol Reform in Korea: Social Cleavage and New Financial Rules Journal of Contemporary Asia 38 (3): 439-452.

Lee, S.-J. and Han, T. 2006. The demise of 'Korea, Inc.': Paradigm shift in Korea's developmental state, Journal of Contemporary Asia 36 (3): 305-324. 
Lee, Keun. 2000. "Corporate Governance and Growth in the Korean Chaebols: A Microeconomic Foundation for the 1997 Crisis." Working Paper Series Vol. 2000-01 February 2000.Seoul National University, mimeo.

Lie, John.1997. Sociology of markets. Annual Review of Sociology . V23: 341-360.

- 1992. "The Concept of Mode of Exchange," American Sociological Review, 57 (4): 508-523.

Lim, Wohyuk. 2003. The Emergence of the Chaebol and the Origins of the Chaebol Problem, Chapter 2, pp.35-52 in Haggard, S., Lim, W and E. Kim .eds. Economic Crisis and Corporate Restructuring in Korea: Reforming the Chaebol. Cambridge University Press

McAdam, Doug. 1982. Political Process and the Development of Black Insurgency 1930-1970. Chicago: University of Chicago Press.

Nee, Victor and Paul Ingram .1998."Embeddedness and Beyond: Institutions, Exchange, and Social Structure." in The New Institutionalism in Sociology: eds. Victor Nee and Mary Brinton. New York: Russell Sage Foundation, 1945 .

North, Douglas C. 1981. Structure and Change in Economic History. New 
York: Norton.

-1990. Institutions, Institutional Change and Economic Performance.

Cambridge University Press.

Oh, Ingyu and Recep Varcin. 2002. "The Mafioso State: State-led Market Bypassing in South Korea and Turkey." Third World Quarterly 23(4-4):711723.

Park, Gil-Sung. 2004. "Economic Restructuring and Social Reformulating: the 1997 Financial Crisis and Its Impact on South Korea," Development and Society, 33, 2:147-64.

Park, Gil-Sung and Kim, Kyung-Pil. 2008. "Financial Crisis and Minority Shareholders' Movement in Korea: The Unfolding and Social Consequences of the Movement." Korean Journal of Sociology 42 (8): 59-76.

Park, Juyoung and Jai S. Mah .2011. Neoliberal Reform and Bipolarisation of Income in Korea, Journal of Contemporary Asia 41 (2): 249-265

Powell, Walter W., and Paul J. DiMaggio, eds. 2012. The New Institutionalism in Organisational Analysis. University of Chicago Press, 2012.

Paek Uk-in. 1993. "Taejung ŭi sam kwa han'guk sahoe pyŏnwha ŭi yoch'e" [Transformations in the Life of the Masses and Korean Society]. In Nara Chŏngch'aek Yŏn'guhoe .ed.. Han'guk sahoe undong ŭi hyŏksin ŭl wihayŏ 
[For the Reform of Social Movements] Seoul: Paeksan Sŏdang. pp. 25-26.

Park, Sang Peel. 2010. "People's solidarity for participatory democracy."

International Encyclopaedia of Civil Society. 1146-1147. Springer US.

PSPD .Ch’amyo yŏndae. 2015. website at http://assembly.pspd.org.kr.

Accessed June 2015.

Proffitt, WT Jr, Spicer A. 2006. "Shaping the Shareholder Activism Agenda: Institutional Investors and Global Social Issues." Strategic Organization 4 (2): 165-190.

Rho, Han-Kyun 2007. Shareholder Activism: Corporate Governance Reforms in Korea. Palgrave Macmillan: New York.

Saleem, N. 2007. 'U.S. Media Framing of Foreign Countries' Image: An Analytical Perspective.” Canadian Journal of Media Studies 2 (1): 13062.

Scott, Richard W. 2001. Institutions and Organisations, 2nd ed. Thousand Oaks: Sage Publications.

Shin, Kwang-Yeong. 2013. Economic Crisis, Neoliberal Reforms, and the Rise of Precarious Work in South Korea. American Behavioral Scientist 57 (3): 335-353. 
Spar, D. L. and La Mure, L. T. 2003. "The Power of Activism: Assessing the impact of NGOs on global business." California Management Review 45 (3): 78-101.

Snow, David, E. Burke Rochford Jr., Steven Worden, and Robert Benford. 1986. "Frame Alignment Processes, Micromobilization, and Movement Participation." American Sociological Review, 51: 464-481.

Snow, David and Robert Benford. 1988. "Ideology, Frame Resonance, and Participant Mobilisation."in Bert Klandermans and Sidney Tarrow .eds.. From Structure to Action: Comparing Social Movement across Cultures. 197218. Greenwich, Conn.: JAI Press.

Steuter, E. and Wills, D. 2009. 'Discourses of dehumanization: enemy construction and Canadian media complicity in the framing of the War on Terror', Global Media Journal -Canadian Edition 2 (2): 7-24.

Tarrow, Sidney.1989. Struggle, Politics and Reform: Collective Action, Social Movements and Cycles of Protest. Cornell University: Western Societies Paper no. 21.

Woo, Jung-en.1991. Race to the Swift: State and Finance in Korean Industrialization. N.Y.: Columbia University Press. 
The Wall Street Journal. 2003. "Pushing Corporate Reform Causes Friction in Korea Sovereign Asset Management Works to Transform SK Group.” June 4, 2003.

Vujakovic, P. 1998. "Reading between the lines: using news media materials for geography", Journal of Geography in Higher Education 22 (1): 147-55.

\footnotetext{
${ }^{1}$ In a study carried out by the Korean Fair Trade Commission (FTC) of 238 listed companies that are part of 46 chaebol, only $0.6 \%$ of 5,692 motions raised in board meetings between May 2011 to April 2012 weren't approved as proposed because of opposition from an external director. (Hangyoreh Simun "Park government stepping back from proposed restrictions on chaebol" Aug.8, 2013).

${ }^{2}$ A 1994 survey of CCEJ members found that the majority were employed in the tertiary sector, with politicians, academics and medical, arts and culture, legal, small business, office and government workers accounting for $59.7 \%$ of the membership. Ministers of religion, members of social organisations, students and housewives accounted for a further $26.4 \%$ of the membership. Educational levels for members are also relatively high and in 1994, 63\% were university graduates (CCEJ 1994: p.327). In the case of the PSPD's shareholder activist arm the Participatory Economy Committee (PEC), by the end of 2000, its 22 executives were either lawyers, accountants, academics or financial specialists (Roh 2007: 86).
} 